\title{
Emergence of Ethnomedical COVID-19 Treatment: A Literature Review
}

\section{Kevin Aprilio (D) \\ Gofarana Wilar (D)}

Department of Pharmacology and Clinical Pharmacy, Faculty of Pharmacy, Universitas Padjadjaran, Sumedang, West Java, 45363, Indonesia
Correspondence: Kevin Aprilio

Department of Pharmacology and Clinical Pharmacy, Faculty of Pharmacy,

Universitas Padjadjaran, Jalan Raya

Bandung-Sumedang KM. 2I, Jatinangor,

Sumedang, West Java, 45363, Indonesia

$\mathrm{Tel} / \mathrm{Fax}+62227796200$

Email kevin18002@mail.unpad.ac.id

\begin{abstract}
The emergence of COVID-19 as a new pandemic in the modern era has led the public to a new perspective of health. In the earlier days of the COVID-19 pandemic, many factors made people go on their own ways in finding its supposed "cure". With conventional medicines' limited availability and access, traditional medicines become more appealing due to its widespread availability and increased perception of safety. Several herbal medicines are then believed to be able to alleviate or cure COVID-19 and its symptoms. Similarities and patterns in herbal medicines being used show local wisdom of the respective communities regarding their knowledge of diseases and its treatment, known as ethnomedicine. Despite not being approved yet by regulatory bodies as a definitive guideline in COVID-19 management, the application of ethnomedicine results in several herbal medicine candidates that show a promising result regarding its efficacy in managing COVID-19. This literature review aims to study how a society and its knowledge of medicine responds to a new and currently developing disease, and whether if that knowledge merits further study in search of a cure for the pandemic. Furthermore, the narrative aspect in this review also explores socio-politics and public health aspects and considerations of non-conventional COVID19 treatment.
\end{abstract}

Keywords: COVID-19, SARS-CoV-2, ethnomedicine, herbal medicine

\section{Plain Language Summary}

COVID-19 pandemic poses new challenges to the clinical field. Research is done to find its treatment. Meanwhile, people are also looking for its alternatives. Several herbal medicine candidates appear as the result that might be beneficial in treating COVID-19. Nevertheless, the lack of knowledge and research of those candidates hinders its public adoption as COVID-19 treatment. Therefore, ethnomedicine, a field studying traditional medicine and the culture around it, might have the potential in guiding researchers in finding COVID-19 treatment from traditional herbal medicine. This paper reviews:

- Traditional herbal medicines used as alternative COVID-19 treatment.

- Herbal medicines' potential for wider adoption in treating COVID-19.

- Social and political climate surrounding herbal medicine use.

- Precautions needed for the use of herbal medicine.

\section{Background}

The emergence of the COVID-19 pandemic has led the public to a shock due to its unprecedented nature and wide scope. Ever since its declaration as a global pandemic by the World Health Organization on March 11, 2020, ${ }^{1}$ many aspects of modern society are brought to a halt in an attempt to slow down its spread by acts 
such as lockdown, restriction on events and gatherings, etc. While being effective in preventing COVID-19 spread, $^{2,3}$ several shortcomings of COVID-19 control protocol still led the public into a panic.

In the United States, for example, disruption of supply chain due to lockdown protocol hindering corporation activities as well as increased demand caused medicine shortages. ${ }^{4}$ Similar phenomena also happened in other parts of the world due to unprecedented increase in demand and disruption in production line and supply. ${ }^{5}$ These drug shortages are further aggravated by misinformation among people that certain drugs can cure or alleviate COVID-19, such as chloroquine/hydroxychloroquine (HCQ). ${ }^{6}$ Misinterpretation of scientific research behind it caused people to stockpile HCQ as an anticipatory purchase, believing its capability of curing COVID-19. This further contributes to HCQ scarcity, as well as other medicines.

Lack of resources for conventional modern medicines forces people to look for its alternatives; one of them is herbal medicines. Despite some preliminary study of available herbal medicine preparations and its curative effects of COVID-19, such as the traditional Chinese medicine Lianhua Qingwen, ${ }^{7,8}$ experts still fear the misguided use of such medicines could do more harm towards people by reliance on unproven alternatives with questionable effectivity. ${ }^{9}$ Regional Office for Africa of the World Health Organization shared a similar sentiment regarding the use of traditional herbal medicine for COVID-19. ${ }^{10}$

Nevertheless, as patterns of similarity emerge in traditional medicines being used for COVID-19, ${ }^{11}$ ethnomedicine can be used as a knowledge basis to "guide" the scientific community in search of specific plants or herbal preparation as a potential cure for COVID-19, amidst the vast number of plants or herbal preparations available in the world. The ethnomedicinal approach also allows representation of local wisdom and knowledge in the modern scientific community, therefore giving such knowledge the scientific reputation and confirmation as its modern counterparts, allowing further utilization of the underrepresented knowledge.

It can be then concluded that, despite the veil of skepticism, the scientific community receives such an approach in search of cures for COVID-19 with open hands. ${ }^{12}$ While knowledge discrepancy of herbal medicine among clinicians poses problems in regards to its adoption, ${ }^{13-17}$ exhibiting mainly in forms of skepticism towards it, herbal medicine remains a potential resource of COVID-19 treatment. Therefore, an adequate amount of research should be given to back up the use of traditional or herbal treatments.

The current situation regarding the COVID-19 pandemic also proves the growing urgency of finding treatment options available for COVID-19 patients. As Chaturvedi et al argued, failure of adapting to the current needs of finding a cure for COVID-19 might pose an ethical dilemma where potentially available treatments are rendered unavailable. ${ }^{18}$

Furthermore, critical and scientific study of traditional treatments for COVID-19-and in general, other ailments -may also act as the basis of counternarrative and education in response to the growing number of misinformation surrounding alternative COVID-19 treatment. As Grimes argued, experts should intervene in the process of information propagation. ${ }^{19}$ Therefore, shifting the conversation to a scientific realm with evidence backup should be an effective way of correcting these inaccurate claims on a theoretical basis.

This study is conducted to understand how local wisdom reacts to a modern phenomenon - in this case, the COVID-19 pandemic - in terms of considerations made in choosing available traditional medicines to be considered able to cure or alleviate COVID-19. The goal is to understand the rationale of herbal medicines used in COVID-19 treatment based on its indication before COVID-19.

However, local wisdom will be taken "as-is" and not be explored further in terms of its specific history, inception, nor propagation. This research will also focus solely on medicines without considering nonpharmacological interventions such as lifestyle changes, physical therapies, and other parts of holistic treatment commonplace in traditional medicine.

\section{Method}

This research is conducted through a literature review based on publicized scientific research regarding traditional or herbal medicines used or potentially used in COVID-19 treatment. Medicines found to be used for COVID-19 are then used to find other supporting publications regarding its indicated use before the emergence of COVID-19. Novel medicines with no previous use aside from COVID-19 cases are excluded from this study.

These collected data will then be interpreted to understand the justification or indication of use in treating COVID-19. Furthermore, these medicines' mechanism of action will also be gathered and interpreted to determine 
whether if the decision of its use for COVID-19 is warranted and whether if there are similarities across these medicines. These findings are also used to classify these medicines to symptomatic treatment-ie, these medicines alleviate COVID-19 symptoms; causative treatment-ie, these medicines, similar to antiviral medicines, can stop SARS-CoV-2 replication; or neither-ie, inconclusive or unproven. Further commentaries regarding the general condition and use of COVID-19 traditional treat measures are also added.

This research is mainly conducted through online databases such as Google Scholar, PubMed, and ScienceDirect. The keywords used in the search include "COVID-19", "SARS CoV-2", "traditional medicine", and/or "herbal medicine". Subsequent research regarding individual medicines will include either its Latin, local, or brand name to explore its medicinal use before COVID19. Furthermore, other relevant publications are also referenced in the narrative section of this article to help describe the condition of herbal medicine use in general as well as other aspects surrounding it.

\section{Result}

After conducting the research, information gathered from various publication are compiled into a table in alphabetical order as seen in Table 1 .

\section{Discussion}

\section{Data and Interpretation}

Of 21 medicines listed and studied, 11 (55\%) of them consist of preparations originating from China as TCM, 7 (33\%) from India as Ayurvedic formula, and 3 (14\%) from various other locations, as illustrated in Figure 1. Indeed, such distinction based on geographic location and/or can be unclear due to the plants' spread in multiple regions and cultural similarity and/or adoption. Zingiberis and Curcuma, for example, can be found spanning within bigger parts of Asia in terms of its availability and use.

Such statistics, however, can be inferred to indicate the number of research and publications made from each country and their respective culture. In this case, one can see that TCM is extensively researched and evaluated alongside its Western medicine counterpart, indicating differences in approach to traditional medicine where Chinese culture arguably embraces their heritage and successfully synthesizes it with new perspectives of Western medicine. This phenomenon, indeed, warrants further research in anthropology, history, or related fields, preferably with a postcolonial perspective. Authors, however, hypothesize that extensive codification of $\mathrm{TCM}^{87}$ and Ayurveda ${ }^{88}$ contributes to its prominence in scientific research.

In terms of effectivity, all studied herbal medicines show a degree of effectivity in treating COVID-19 through symptomatic mechanism, causative, or both, as illustrated in Figure 2. This might owe to most of its established use as treatments for respiratory infection based on various of its underlying ethnomedical approach $(\mathrm{n}=13 ; 62 \%)$, being the hallmark of SARS-CoV-2 infection symptoms.

Unfortunately, the variety of mechanisms through which these medicines, or its constituent herbs, work prevents its interpretation in finding common mechanisms through which these herbal medicines work in alleviating COVID-19. Future studies are warranted in this aspect to optimize its use in COVID-19 as well as, where applicable, replace rare herbs used in some formulations for ecological and accessibility considerations.

\section{Appeals of Herbal Medicine}

Despite not being adopted yet into any clinical guidelines and, furthermore, being generally faced with skepticism with much of conventional medicine practitioners (ie, clinicians), ${ }^{89,90}$ perception is going on a positive trend and is generally improving. ${ }^{91}$ Several beneficial aspects of herbal medicine contribute to its current use and may be further used in clinical settings.

The cultural proximity of ethnomedicine and its herbalderived medicines also play a key role in its use. Firstly, despite being an ill-advised notion, the majority of people use herbal medicine with belief that its natural origin contributes to its safety. ${ }^{92-94}$ Furthermore, as access to conventional medicine might be lacking in several circumstances, traditional medicine-more specifically, herbal medicine-serves as an alternative. ${ }^{95}$ Its cultural root uses readily available resources in each geographic area, making herbal medicine more widespread for the given area. Further elaborations, especially regarding its impact, are available in the 'Prospect and Outlook' section.

\section{Challenges of Herbal Medicine}

Despite offering interesting appeals, the wider use of herbal medicine remains a long journey that requires a methodical approach to overcome its shortcomings. As mentioned previously, many factors hinder the wider use and adoption of herbal medicine in clinical settings. 
Table I Research Result

\begin{tabular}{|c|c|c|c|c|}
\hline Medicine Name & Use in COVID-19 & Use Before COVID-I9 & Mechanism of Action & Interpretation \\
\hline $\begin{array}{l}\text { Allium sativum (garlic). } \\
\text { Origin: India }\end{array}$ & $\begin{array}{l}\text { Indicated for the prevention } \\
\text { of COVID-19 infection } \\
\text { through its } \\
\text { immunomodulatory and } \\
\text { antibacterial properties. }{ }^{20,21}\end{array}$ & $\begin{array}{l}\text { Indication of antibacterial, } \\
\text { antifungal, antiviral, antioxidant, } \\
\text { anti-inflammatory effects, etc. }{ }^{22}\end{array}$ & $\begin{array}{l}\text { Lectin, as the active compound in } \\
\text { Allium sativum, inhibits viral } \\
\text { attachment in the early } \\
\text { replication cycle and end of viral }^{23} \\
\text { cycle. }^{23}\end{array}$ & $\begin{array}{l}\text { Symptomatic, as common } \\
\text { consensus. }{ }^{20}\end{array}$ \\
\hline $\begin{array}{l}\text { Artemisia afra (African } \\
\text { wormwood). }{ }^{24} \\
\text { Origin: African } \\
\text { countries. }\end{array}$ & $\begin{array}{l}\text { Claimed by several people to } \\
\text { cure COVID- } 19{ }^{25} \text { with some } \\
\text { evidence in its in vitro } \\
\text { efficacy. }\end{array}$ & Used in malarial infection. ${ }^{27}$ & $\begin{array}{l}\text { Artemisinin and its derivatives } \\
\text { can bind any of SARS-CoV-2 } \\
\text { target proteins (ie its } \\
\text { glycoprotein, spike ectodomain } \\
\text { structural protein, main protease, } \\
\text { or spike receptor-binding } \\
\text { domain), preventing viral binding } \\
\text { to the host's ACE2 receptor. } \\
26,28\end{array}$ & Potentially causative. \\
\hline $\begin{array}{l}\text { Asparagus } \\
\text { racemosus (shatavari). } \\
\text { Origin: India }\end{array}$ & $\begin{array}{l}\text { Indication of therapeutic } \\
\text { effects through viral protein } \\
\text { binding. }{ }^{29}\end{array}$ & $\begin{array}{l}\text { Known as a part of rejuvenation } \\
\text { medicine of Ayurveda (rasayana), } \\
\text { with antitussive, antibacterial, } \\
\text { immunomodulatory, } \\
\text { immunoadjuvant effects, } \\
\text { etc. }^{20,30,31}\end{array}$ & $\begin{array}{l}\text { In silico studies show } \\
\text { phytochemical activities through } \\
\text { binding of SARS-CoV-2 spike } \\
\text { receptor-binding domain, } \\
\text { attenuating the severity of } \\
\text { COVID-19.29 }\end{array}$ & $\begin{array}{l}\text { Causative due to its effect in } \\
\text { inhibiting viral activities as well } \\
\text { as symptomatic due to its } \\
\text { immunomodulatory and } \\
\text { immunoadjuvant properties. }\end{array}$ \\
\hline $\begin{array}{l}\text { Bai He Gu Jin Tang } \\
\text { decoction }^{32} \text { of various } \\
\text { herbs. } \\
\text { Origin: PRC }\end{array}$ & $\begin{array}{l}\text { Indicated for the treatment of } \\
\text { severe COVID-19 infection. }{ }^{33}\end{array}$ & $\begin{array}{l}\text { Treatment of cough on pregnant } \\
\text { patients with indication of the } \\
\text { expectorant activity of its } \\
\text { ingredients. }^{34}\end{array}$ & $\begin{array}{l}\text { Suppression of viral-induced NF- } \\
\kappa B \text { activation and expression of } \\
\text { IL-6, IL-8, TNF- } \alpha \text {, IP-I0, and } \\
\text { MCP-I. Impairment of viral } \\
\text { RNP. }^{33} \\
\text { Decreases the level of } \\
\text { inflammatory cytokines in the } \\
\text { early stages of infection. }\end{array}$ & $\begin{array}{l}\text { Symptomatic through its effects } \\
\text { on COVID-19 symptoms, ie } \\
\text { coughing and difficulty in } \\
\text { breathing. }\end{array}$ \\
\hline $\begin{array}{l}\text { Curcuma longa } \\
\text { L. (turmeric). }{ }^{20,35} \\
\text { Origin: India, as well as } \\
\text { other countries. }\end{array}$ & $\begin{array}{l}\text { Indication of symptomatic } \\
\text { activity as well as therapeutic } \\
\text { activity through in-silico study } \\
\text { and its activity in similar } \\
\text { viruses. }^{36,37}\end{array}$ & $\begin{array}{l}\text { Indication of gastrointestinal, } \\
\text { respiratory, inflammatory, and } \\
\text { cardiovascular disorders, as well } \\
\text { as antidiabetic, hepatoprotective, } \\
\text { neuroprotective, and } \\
\text { chemoprotective effects. }^{38}\end{array}$ & $\begin{array}{l}\text { Several molecular mechanisms of } \\
\text { curcumin may have potential in } \\
\text { treating COVID-19, such as } \\
\text { inhibitory effects on Toll-like } \\
\text { receptors, NF- } \kappa \mathrm{B} \text {, inflammatory } \\
\text { cytokines and chemokines, and } \\
\text { bradykinin, as well as its } \\
\text { antioxidant, antiapoptotic, and } \\
\text { antifibrotic properties. }^{36}\end{array}$ & $\begin{array}{l}\text { Possibly symptomatic, as despite } \\
\text { without specific research in } \\
\text { COVID-19 treatment, curcumin } \\
\text { is thought to be able to alleviate } \\
\text { its symptoms. }\end{array}$ \\
\hline $\begin{array}{l}\text { Cyperus rotundus Linn. } \\
\text { rhizoma (nut-grass) } \\
\text { decoction. }^{20} \\
\text { Origin: India }\end{array}$ & $\begin{array}{l}\text { Used as a warm decoction to } \\
\text { alleviate symptoms, with } \\
\text { further research indicating } \\
\text { therapeutic effect by viral } \\
\text { protease inhibition. }^{20,39}\end{array}$ & $\begin{array}{l}\text { Various symptomatic alleviation, } \\
\text { including analgesic, antiallergic, } \\
\text { antiemetic, etc. }^{40}\end{array}$ & $\begin{array}{l}\text { In silico study of its } \\
\text { phytoconstituents, namely } \beta \text { - } \\
\text { amyrin and stigmasta-5,22-dien } \\
-3 \text {-ol, indicated its capacity in } \\
\text { inhibiting } M^{\text {pro }} \text { of SARS-CoV-2. }{ }^{39}\end{array}$ & Possibly causative. ${ }^{39}$ \\
\hline $\begin{array}{l}\text { Gancao Ganjiang } \\
\text { decoction }^{41} \text { of } \\
\text { Glycyrrhizae radix } \\
\text { preparata (licorice, } \\
\text { yashtimadhu) and } \\
\text { Zingiberis rhizoma } \\
\text { (ginger). } \\
\text { Origin: PRC }\end{array}$ & $\begin{array}{l}\text { Indicated for treatment in the } \\
\text { early phase of COVID-19 } \\
\text { infection, indicates } \\
\text { symptomatic relief. }^{42}\end{array}$ & $\begin{array}{l}\text { Licorice is indicated for use in } \\
\text { respiratory diseases, as well as } \\
\text { acting as a "complement" for } \\
\text { other medicines. } \\
\text { Gi,44 } \\
\text { effects for various diseases, } \\
\text { including antipyretic, antiemetic, } \\
\text { antiinflammation, etc. }{ }^{45}\end{array}$ & $\begin{array}{l}\text { At the membrane level, } \\
\text { glycyrrhizic acid (GLR) induces } \\
\text { cholesterol-dependent } \\
\text { disorganization of lipid rafts used } \\
\text { in SARS-CoV-2 entry. At the } \\
\text { intracellular level, GLR traps } \\
\text { HMGBI and blocks its alarming } \\
\text { functions. }{ }^{46}\end{array}$ & $\begin{array}{l}\text { Symptomatic, as indicated by } \\
\text { TCM. } \\
\text { Licorice itself, however, may } \\
\text { show causative effect due to its } \\
\text { antiviral activity. }{ }^{44}\end{array}$ \\
\hline
\end{tabular}

(Continued) 
Table I (Continued).

\begin{tabular}{|c|c|c|c|c|}
\hline Medicine Name & Use in COVID-19 & Use Before COVID-19 & Mechanism of Action & Interpretation \\
\hline $\begin{array}{l}\text { Kaloba }^{\circledR} \text { tablets EPs } \\
7630^{\circledR 47} \text { of Pelargonium } \\
\text { sidoides extract. } \\
\text { Origin: Germany }\end{array}$ & $\begin{array}{l}\text { Used to attenuate the } \\
\text { severity of respiratory } \\
\text { syndrome of human } \\
\text { coronavirus infection. }{ }^{48}\end{array}$ & $\begin{array}{l}\text { Registered in Germany since } \\
2005 \text { as a standardized extract for } \\
\text { the treatment of acute } \\
\text { bronchitis. }{ }^{49}\end{array}$ & $\begin{array}{l}\text { Underlying immunomodulatory } \\
\text { and cytoprotective effects } \\
\text { through inhibition of enveloped } \\
\text { virus replication-ie human } \\
\text { coronavirus, inhibition of } \\
\text { interactions between bacteria and } \\
\text { host cells, and increment of ciliary } \\
\text { beat frequency on respiratory } \\
\text { cells. }\end{array}$ & $\begin{array}{l}\text { Causative, owing to its } \\
\text { capability in inhibiting viral } \\
\text { replication. }\end{array}$ \\
\hline $\begin{array}{l}\text { Lianhua Qingwen } \\
\text { capsule }^{42} \text { of various } \\
\text { herbs and minerals. } \\
\text { Origin: PRC }\end{array}$ & $\begin{array}{l}\text { Indicated for treatment in } \\
\text { COVID-19 patients, resulting } \\
\text { in faster recovery from its } \\
\text { symptoms. }\end{array}$ & $\begin{array}{l}\text { Indicated for respiratory diseases, } \\
\text { particularly influenza. }\end{array}$ & $\begin{array}{l}\text { Inhibits decrement of } \mathrm{CD}^{+} \text {and } \\
\mathrm{CD} 8^{+} \text {level and protects cellular } \\
\text { immune response. }\end{array}$ & $\begin{array}{l}\text { Symptomatic by most available } \\
\text { publications, albeit several leads } \\
\text { have indicated causative } \\
\text { possibilities. }{ }^{52}\end{array}$ \\
\hline $\begin{array}{l}\text { Maxingshigan Tang } \\
\text { decoction }{ }^{32} \text { of various } \\
\text { herbs. } \\
\text { Origin: PRC }\end{array}$ & $\begin{array}{l}\text { Indicated for the treatment of } \\
\text { severe COVID-19 infection. }{ }^{32}\end{array}$ & $\begin{array}{l}\text { Treatment of HINI influenza, } \\
\text { leading to a reduction in fever } \\
\text { time. }^{53}\end{array}$ & $\begin{array}{l}\text { Suggested to interact with } \\
\text { thrombin and Toll-like receptor } \\
\text { signaling for its anti-inflammatory } \\
\text { effects on COVID-19.54 }\end{array}$ & Symptomatic. \\
\hline $\begin{array}{l}\text { Qingfei Paidu } \\
\text { decoction }{ }^{41} \text { of various } \\
\text { herbs and minerals. } \\
\text { Origin: PRC }\end{array}$ & $\begin{array}{l}\text { Indicated for treatment in } \\
\text { COVID-19 patients through } \\
\text { its immunomodulatory } \\
\text { effects. }{ }^{55} \text { It is also indicated } \\
\text { for COVID-19 } \text { treatment. }^{42}\end{array}$ & $\begin{array}{l}\text { The complex nature of this } \\
\text { preparation has limited its } \\
\text { research. However, it is often } \\
\text { indicated for respiratory } \\
\text { problems related to "qi } \\
\text { imbalances". }{ }^{6}\end{array}$ & $\begin{array}{l}\text { Targets human coronavirus as } \\
\text { well as pneumonia and ACE2 co- } \\
\text { expression proteins through } \\
\text { miRNA (MIRI83), kinase } \\
\text { (CDK7), and TF (LXR). }{ }^{57}\end{array}$ & $\begin{array}{l}\text { Causative, as indicated by its use } \\
\text { in emergency COVID-19 } \\
\text { guidelines issued by various } \\
\text { authorities in PRC }{ }^{56} \text { and by its } \\
\text { capacity in viral replication } \\
\text { interruption. }\end{array}$ \\
\hline $\begin{array}{l}\text { Sang Ju Yin }{ }^{32} \text { of various } \\
\text { herbs. } \\
\text { Origin: PRC }\end{array}$ & $\begin{array}{l}\text { Indicated for the treatment of } \\
\text { mild COVID-19 infection, } \\
\text { particularly with heavy } \\
\text { cough. } \\
\text {.2 }\end{array}$ & $\begin{array}{l}\text { Indication of immunomodulatory } \\
\text { properties. }^{58}\end{array}$ & $\begin{array}{l}\text { Forsythia suspensa, a herb } \\
\text { constituting Sang Ju Yin, } \\
\text { demonstrates activity in the T-cell } \\
\text { receptor cell pathway, inhibiting } \\
\text { T-cell activation }{ }^{59,60}\end{array}$ & $\begin{array}{l}\text { Symptomatic, mainly due to its } \\
\text { immunomodulatory effects. } \\
\text { Further research regarding its } \\
\text { specific mechanism to COVID- } \\
19 \text { is still not found. }\end{array}$ \\
\hline $\begin{array}{l}\text { Shegan Mahuang }{ }^{41} \text { of } \\
\text { various herbs. } \\
\text { Origin: PRC }\end{array}$ & $\begin{array}{l}\text { Indicated for COVID-19 } \\
\text { treatment through its } \\
\text { protective nature against viral } \\
\text { infection damage. }{ }^{42,61}\end{array}$ & $\begin{array}{l}\text { Indicated for respiratory diseases, } \\
\text { particularly asthmatic airway } \\
\text { restriction. }^{62}\end{array}$ & $\begin{array}{l}\text { Attenuation of asthmatic airway } \\
\text { hyperresponsiveness through the } \\
\text { inhibition of Th2 and Th17 } \\
\text { differentiation; promotion of } \\
\text { CD4, FOXP3, and Treg } \\
\text { generation; and suppression of } \\
\text { mTOR and NF-KB activities. }{ }^{63}\end{array}$ & $\begin{array}{l}\text { Symptomatic, mainly due to its } \\
\text { mechanism of action in } \\
\text { modulation and suppression of } \\
\text { various cytokines. } .^{63}\end{array}$ \\
\hline $\begin{array}{l}\text { Shuanghuanglian of } \\
\text { various herbs. }{ }^{64} \\
\text { Origin: PRC }\end{array}$ & $\begin{array}{l}\text { Indicated for COVID-19 } \\
\text { treatment through its } \\
\text { previous use treating SARS. }{ }^{42}\end{array}$ & $\begin{array}{l}\text { Indication of use for acute upper } \\
\text { respiratory tract infection, with } \\
\text { clinical trials demonstrating its } \\
\text { possible effectivity. }{ }^{65,66}\end{array}$ & $\begin{array}{l}\text { Inhibition of SARS-CoV-2 3CLpro } \\
\text { and PLpro, assumedly from its } \\
\text { baicalin and baicalein content, } \\
\text { resulting in viral replication } \\
\text { inhibition. }{ }^{67}\end{array}$ & Causative. \\
\hline $\begin{array}{l}\text { Solanum sp. }{ }^{68} \\
\text { Origin: Congo, Africa }\end{array}$ & $\begin{array}{l}\text { A pilot study indicates } \\
\text { potential benefits to COVID- } \\
19 .^{68}\end{array}$ & $\begin{array}{l}\text { Indication for various effects } \\
\text { depending on species, such as } \\
\text { bronchodilator, antibacterial, } \\
\text { antiviral, analgesic, } \\
\text { hepatoprotective, } \\
\text { cardioprotective, etc. }^{68}\end{array}$ & $\begin{array}{l}\text { Glycoalkaloids in Solanum sp. } \\
\text { shows interaction with SARS- } \\
\text { CoV-2 } \text { protease. }^{68}\end{array}$ & $\begin{array}{l}\text { Preliminary findings from similar } \\
\text { viruses may indicate causative } \\
\text { qualities. }\end{array}$ \\
\hline
\end{tabular}

(Continued) 
Table I (Continued).

\begin{tabular}{|c|c|c|c|c|}
\hline Medicine Name & Use in COVID-19 & Use Before COVID-I9 & Mechanism of Action & Interpretation \\
\hline $\begin{array}{l}\text { Tinospora cordifolia } \\
\text { (heart-leaved } \\
\text { moonseed, guduchi). }{ }^{20} \\
\text { Origin: India }\end{array}$ & $\begin{array}{l}\text { Indication of therapeutic } \\
\text { effects through viral protein } \\
\text { binding. }{ }^{69}\end{array}$ & $\begin{array}{l}\text { Known as a part of rejuvenation } \\
\text { medicine of Ayurveda (rasayana), } \\
\text { with immunomodulatory, } \\
\text { antidiabetic, antitoxic, anti-HIV, } \\
\text { antibacterial, antioxidant }^{\text {activities, etc. }}{ }^{20,70}\end{array}$ & $\begin{array}{l}\text { Stimulation of proteolytic } \\
\text { maturation of viral RNA into } \\
\text { functional proteins, namely RNA } \\
\text { polymerase, endoribonuclease, } \\
\text { and exoribonuclease, hampering } \\
\text { the host's intrinsic immune } \\
\text { system response. }^{70}\end{array}$ & $\begin{array}{l}\text { Causative due to its effect in } \\
\text { inhibiting viral activities as well } \\
\text { as symptomatic due to its } \\
\text { immunomodulatory properties. }\end{array}$ \\
\hline $\begin{array}{l}\text { Vetiveria zizanioides } \\
\text { L. Nash (vetiver, khus) } \\
\text { decoction. }{ }^{20} \\
\text { Origin: India }\end{array}$ & $\begin{array}{l}\text { Indicated to restore bodily } \\
\text { balance. }^{71}\end{array}$ & $\begin{array}{l}\text { Indication of antibacterial } \\
\text { activities. }^{72} \text { Empirically used for } \\
\text { mouth ulcer, fever, headache, } \\
\text { etc. }^{73}\end{array}$ & $\begin{array}{l}\text { Potential capability in binding with } \\
\text { spike protein of SARS-CoV-2, } \\
\text { changing its affinity to ACE } 2 \\
\text { receptor, restricting viral entry to } \\
\text { human cell. }^{73}\end{array}$ & Possibly causative. \\
\hline $\begin{array}{l}\text { Withania somnifera } \\
\text { (Indian ginseng, } \\
\text { ashwagandha). } \\
\text { Origin: India }\end{array}$ & $\begin{array}{l}\text { Indication of therapeutic } \\
\text { effects through viral activity } \\
\text { suppression by viral protein } \\
\text { binding. }{ }^{69,74}\end{array}$ & $\begin{array}{l}\text { Known as a part of rejuvenation } \\
\text { medicine of Ayurveda (rasayana), } \\
\text { with antioxidant, } \\
\text { immunomodulatory, antibacterial } \\
\text { effects, etc. }^{20,75,76}\end{array}$ & $\begin{array}{l}\text { Withanone from Withania } \\
\text { somnifera reduces the } \\
\text { glycosylation of SARS-CoV-2 via } \\
\text { interaction with Asn343, } \\
\text { inhibiting viral replication. }^{76}\end{array}$ & $\begin{array}{l}\text { Causative due to its effect in } \\
\text { inhibiting viral activities as well } \\
\text { as symptomatic due to its } \\
\text { immunomodulatory properties. }\end{array}$ \\
\hline $\begin{array}{l}\text { Xuebijing injection }{ }^{33} \text { of } \\
\text { various herbs. } \\
\text { Origin: PRC }\end{array}$ & $\begin{array}{l}\text { Indicated for the treatment of } \\
\text { severe COVID-19 infection } \\
\text { through inhibition of } \\
\text { inflammatory cytokines. }{ }^{33,77}\end{array}$ & $\begin{array}{l}\text { Treatment of rheumatoid arthritis } \\
\text { through various cytokines } \\
\text { downregulation, severe sepsis } \\
\text { with disseminated intravascular } \\
\text { coagulation, and pneumonia. }^{78-80}\end{array}$ & $\begin{array}{l}\text { Inhibition of IL- } 6 \text {, TNF- } \alpha \text {, and } \\
\text { other cytokines. }{ }^{77}\end{array}$ & $\begin{array}{l}\text { Symptomatic, with remarks on } \\
\text { its effects on downregulating } \\
\text { inflammatory cytokines; playing } \\
\text { a key role in its use for severe } \\
\text { COVID-19 infection. }\end{array}$ \\
\hline $\begin{array}{l}\text { Yin Qiao } \operatorname{San}^{32} \text { of } \\
\text { various herbs. } \\
\text { Origin: PRC }\end{array}$ & $\begin{array}{l}\text { Indicated for the treatment of } \\
\text { mild COVID-19 infection, } \\
\text { particularly with a high } \\
\text { fever. }^{32}\end{array}$ & $\begin{array}{l}\text { Treatment of common cold or } \\
\text { upper respiratory infection and } \\
\text { fever in children. }{ }^{81,82}\end{array}$ & $\begin{array}{l}\text { Improvement of lysozyme } \\
\text { enzyme activity and enhancement } \\
\text { of SlgA found in saliva. }{ }^{83}\end{array}$ & Symptomatic. \\
\hline $\begin{array}{l}\text { Yu Ping Feng San } \\
\text { decoction }{ }^{32} \text { of Astragali } \\
\text { radix, Atractylodis } \\
\text { macrocephale spora, } \\
\text { and Saposhnikoviae } \\
\text { radix. } \\
\text { Origin: PRC }\end{array}$ & $\begin{array}{l}\text { Indicated for the prevention } \\
\text { of COVID-19 infection } \\
\text { through the protection of } \\
\text { lungs' "natural qi" against } \\
\text { "pathogenic qi" and reduction } \\
\text { of phlegm. }\end{array}$ & $\begin{array}{l}\text { Treatment of respiratory } \\
\text { infection and disease, including } \\
\text { COPD. }^{84}\end{array}$ & $\begin{array}{l}\text { Regulation of core pathways, such } \\
\text { as AGE-RAGE, PI3K-AKT, TNF, } \\
\text { apoptosis pathway, etc. }^{85} \\
\text { Modulation of targets, such as } \\
\text { PTGS2 (COX2), PTGSI (COXI), } \\
\text { IL-6, CASP3, NOS3, TNF, etc. }\end{array}$ & $\begin{array}{l}\text { Symptomatic, albeit with } \\
\text { a possibility of being causative } \\
\text { due to its antiviral activities. }\end{array}$ \\
\hline
\end{tabular}

Abbreviations: PRC, People's Republic of China; TCM, traditional Chinese medicine.

Lack of study and profiling of herbal medicine poses uncertainty in evidence-based medicine practice. While some herbal medicines have undergone clinical trials, ie, human in vivo trials, plenty of others have only undergone preclinical trials, ie, in silico, in vitro, or animal in vivo trials, or even none. This use of clinically unproven medicine poses dangers to patients through the use of "placebo-based medicine", resulting in delayed proper care and loss of opportunity cost that may end up exacerbating the COVID-19 pandemic. ${ }^{9,96}$

Furthermore, as herbal medicine often involves the use of whole plants, the lack of biomolecular profiling also raises an issue in its adoption. This raises problems regarding its efficacy, safety, as well as interaction with other medicines, such as in the case with Artemisia. ${ }^{97}$ While the effectivity of herbal medicine can be proven through a comparative study, Firenzuoli and Gori equate the lack of study of herbal medicines' chemical constituents and its mechanism of action as reliance on a "black box". ${ }^{98}$ This owes to the plethora of variables affecting plants, which may result in a difference in each plants' chemical constituents and amount, leading to treatment inconsistency, adverse effects, as well as possible interaction with other medicines.

One of the examples signifying the importance of in vivo testing and biomolecular mechanism profiling can be seen in 
the use of HCQ for COVID-19. Subsequent in vivo testing of HCQ fail to demonstrate its efficacy in treating COVID-19 despite promising in vitro results. ${ }^{99-101}$ Further researches indicated that HCQ only inhibits one of many pathways of SARS-CoV-2 infection to human lung cells that are not available in previously-used in vitro test cells. ${ }^{102}$ This finding can then conclude the importance of further research needed to justify the use of herbal medicine, especially regarding COVID-19.

\section{Socio-Politics of COVID-19 Treatment}

The politicization of COVID-19 treatment with the use of herbal, traditional, or generally unconventional medicine must be acknowledged. This is usually done to maintain public order to diminish panic among the society during the pandemic, oftentimes in place of more effective yet less appealing measures and regulations such as lockdown and quarantine. In these cases, medicines-particularly herbal medicine-are marketed by various people with exaggerated claims without adequate scientific research backing them. ${ }^{103}$

A more prominent example of such an act is in Donald J. Trump's presidency of the United States, where he advocated what was yet-to-be proven HCQ, azithromycin, and remdesivir. ${ }^{104}$ It has to be acknowledged that these acts exacerbate public distrust of the government and

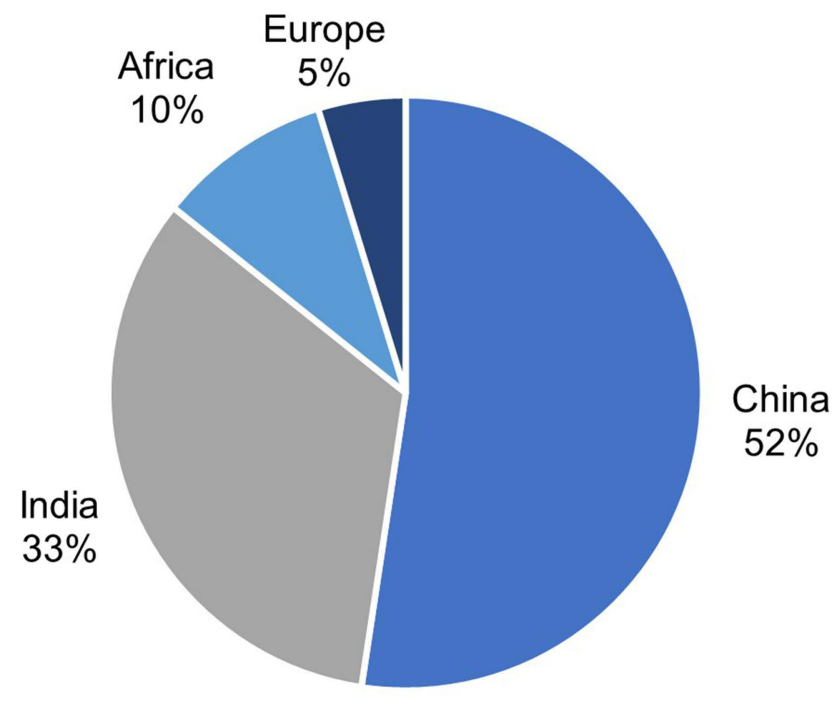

- China - India - Africa - Europe

Figure I Geographic spread of studied herbal medicines. scientific communities, which ends up undermining COVID-19's danger and measures taken to contain it. ${ }^{105}$

Furthermore, people's political partisanship and lack of union in politician's stance regarding the COVID-19 pandemic further worsen the spread of misinformation and conspiracy theories surrounding it. The view of the COVID-19 pandemic as a political move further invalidates authoritative bodies' pandemic management measures, further worsening these people's health outcome. ${ }^{106,107}$

In terms of herbal medicines, its use is often based on exaggerated claims regarding its curative effect exploiting its preconceived positive belief and outlook. Several herbal medicines have been used, despite lack of evidence, not only by pseudoscientific "alternative health advocate" 108 but also by politicians. ${ }^{25,109}$

These issues end up fueling the misinformation havoc by adding inaccurate information that buries and dilutes accurate ones; making it harder to find correct information of the pandemic. As evidenced by Enders et al, the belief of misinformation regarding COVID-19 is linked with risky behaviors that would further propagate COVID-19. ${ }^{110}$ Furthermore, authors argue that - as the case of Artemisia afra's use - exaggerated claims of herbal medicines can portray herbal medicine badly as "unscientific", etc.

\section{Slippery Slopes}

Appeals and challenges surrounding the use of herbal medicine, particularly within the context of the COVID-19 pandemic, puts it on a slippery slope of polar extremes in stances regarding it. On one side, traditional medicine is accepted as-is without further scrutiny of evidence-based medicine practice, leading to what is, at best, exaggerated claims or, at worst, pseudoscience. This approach to herbal medicine has unfortunately been exploited by parties, oftentimes in bad faith. On

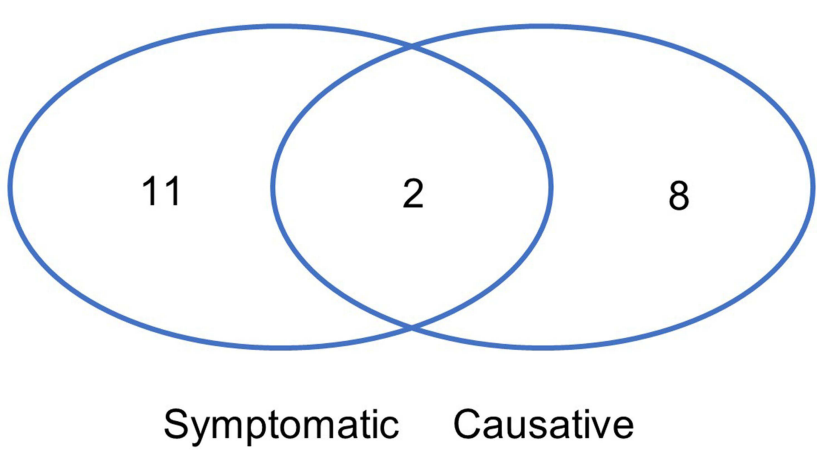

Figure 2 Effectivity of studied herbal medicines, numbers denoting $\mathrm{n}$ value. 
the other side, the skeptical-borderline-cynical approach also comes with its risk of potentially hampering discoveries.

This phenomenon shows the delicacy of aspects related to the development of herbal medicine and its adoption among clinicians as well as people. For example, herbal medicines' perception of safety may be used in health promotion to increase people's trust, ${ }^{111}$ while as well create an illusion of safety ${ }^{112}$ and reliance on unproven medicine and further exacerbation of COVID-19 itself. Tabish described that reliance on unproven complementary and alternative medicine over traditional medicine is in and of itself reliance on placebo, which might result in loss of opportunity cost when patients end up foregoing effective treatments available for their ailments. ${ }^{96}$

The juxtaposition between Western medicine and local traditional medicine oftentimes leads to a dichotomy between evidence-based scientific rigor and "mythical folklore" of unsupported claims. However, as evident in this research, such assumption cannot be held as true as all medicine shows some degree of correlation through symptomatic relief of its symptoms. This finding is further supported by some preliminary studies ${ }^{64,113}$ and metaanalysis $^{11,114}$ showing promising theoretical basis as well as evidence regarding the use of herbal preparation. Some herbal preparations or plants used in traditional medicine, as stated above in Table 1, have also shown preliminary clinical evidence of its therapeutic effect, further supporting its use in COVID-19 treatment.

\section{Significance and Capacity}

As authors have elaborated before, it can be concluded that most problems arising from the use of herbal medicine in the present time are the social aspects that surround it; that is the problem revolves around how society perceives and treats its use in the context of contemporary knowledge. Therefore, change through regulation and education-to clinicians, patients, and people in general — should be able to shift the paradigm to bring herbal medicine use.

One example is the view of herbal medicine exclusively as complementary medicine, which hinders its research and leads to a loose regulation of its use. As of now, with most jurisdictions classifying herbal preparations as supplements, manufacturers can make claims that are not as rigorously proven as its conventional medicine counterparts. ${ }^{115}$ Societal view towards herbal medicine as the superior counterparts of conventional medicine also leads to reliance on subjective claims among its users. $^{112}$
Looking into the history of pharmacy, ${ }^{116}$ one can also see its roots of drug discovery and use in plants. As many medicines-from antipyretic acetylsalicylic acid to chemotherapeutic paclitaxel are based on plant metabolites - have its origin as plant metabolites, and many other medicines are made based on these plant metabolites' mechanism of action, it is warranted to retrace and not forego the root of pharmaceutical science while also applying other knowledge built upon it. The possibility of novel active ingredients found in new medicinal plants may serve as a benefit and justification for further research.

\section{Prospect and Outlook}

Wider adoption of traditional medicine, and within itself herbal medicine, may bring several outcomes that might better the conventional medicine.

Demaio elaborated regarding the importance of appropriating health education to a society's particular culture. ${ }^{111}$ Integration of local wisdom through ethnomedicine should work in health promotion and education in general. Regarding the COVID-19 pandemic, this approach also helps in terms of partnership and adaptation of knowledge through the involvement of local practitioners and their knowledge of both the medicine and people in the society, further leading to a communityspecific promotion, as well as empowerment of the community using resources available to them.

The need for such a socio-cultural approach is further apparent in the COVID-19 pandemic due to the prevalent misinformation and distrust of science surrounding it, as mentioned before. A community-specific approach, which may or may not include ethnomedicine and herbal medicine, may help educate people and gain their trust in the healthcare system, therefore maximizing the efficacy of COVID-19 control. However, it is to be remembered that this approach should not be a way to coopt a culture, as also argued by Fofana. ${ }^{117}$

Furthermore, herbal medicine has also demonstrated its use as preventive medicine for various diseases, including the previous SARS epidemic. ${ }^{118}$ While no proper studies have been conducted in terms of the preventive role of herbal medicine in COVID-19 infection, its potential cannot be undermined. ${ }^{119}$ This use is further supported by traditional medicine's general paradigm that one's body can heal itself with medicines acting as an aid to reinforce it, which also includes the body's defense mechanism. General availability and accessibility of herbal medicine 
also help its role as preventive measures, in conjunction with other measures such as mask-wearing and general hygiene.

While evidence-based medicine and ethnomedicine encounter issues in its reconciliation, Jonas highlighted this issue and proposed a new structure of thinking that might help approach ethnomedicine and complementary and alternative medicine. ${ }^{120}$ Owing to the dynamic nature of local wisdom and its deep integration into society, local wisdom and its practice will remain in the society and can be used to respond to future diseases. Therefore, this analytical tool and framework can be used to approach more diseases to come.

\section{Limitation}

While authors strive for the accuracy of this study, several shortcomings should remain to be considered. Nevertheless, the authors hope that this article would serve as a reference and justification for future more indepth research on this topic. Authors hope for future research from both medical science and social science researchers in this area.

The construction of this study as a literature review might impose a positive bias on its result due to the inherent publication bias of academic research. It also limits available data to medicines that have been published, which may pose selection bias and therefore might not present a complete view of ethnomedicine for COVID-19.

\section{Conclusion}

Traditional medicine proves to be an underexposed realm of medical knowledge. Its underrepresentation in the current medical field has been a loss in terms of opportunity cost, as its benefits have been masked by the problems that it continues to face. However, under the pressure of the COVID-19 pandemic, the medical field is forced to be able to adapt to a novel disease with its scale and burden. Therefore, in that regard, proposes for researchers to reconsider the potentials of ethnomedicine, particularly medicine, as a resource of potential treatments for COVID-19 as well as, possibly, other old or new diseases.

Among samples of ethnomedical COVID-19 herbal medicines used in this review $(\mathrm{n}=21)$, all have demonstrated its potential in treating COVID-19 through various mechanisms, indicating ethnomedicine's capacity in adapting to novel diseases. This demonstrates ethnomedical herbal medicine's general capacity in responding to new diseases - in this case, COVID-19-through adaptation of medicines used prior. While unsampled medicines in some cases may fail to demonstrate such efficacy, these failures should not be generalized as inadequacy of ethnomedicine itself; rather, a part of medicine discovery steps just like its conventional counterparts.

Furthermore, the intricacy of herbal medicine-especially in relation to ethnomedicine and, therefore, culture - gives a unique facet of medicine that can be a doubleedged sword. While its cultural aspect can be used for clinicians to reach out to people and provide more widespread, inclusive, and accessible healthcare, it can also be misused as justification to undermine the scientific approach to medicine. A multidisciplinary approach is needed in this regard to not only study the medicines available in culture but to also "give back" the knowledge to its society to ensure its equitable access.

Regardless, ignoring the potential of what ethnomedicine has to offer would constitute an opportunity loss, especially in a condition as dire as the current pandemic. The pandemic, therefore, should catalyze the further research and codification of this field, as its capacity has been used in previous epidemics. The perpetually evolving nature of this field would make this analytical tool a substantial basis for use in studying the treatment of diseases of the present or future.

\section{Acknowledgments}

Authors express deep gratitude to Rizky Abdulah for his guidance in this research and grant through Universitas Padjadjaran, Atika, A. P., Kusumo, P. S., Indrajaya, R. M., and other friends of LPPMD Universitas Padjadjaran for the discussions and insights, and colleagues in the Faculty of Pharmacy, Universitas Padjadjaran. Funding for article processing charge (APC) is granted by Universitas Padjadjaran.

\section{Author Contributions}

All authors have contributed substantially to the creation process of this review through conception, design, drafting, revision, and analysis, and agreed on its publication and accountability.

\section{Disclosure}

Mr Kevin Aprilio reports grants from Universitas Padjadjaran, during the conduct of the study. The authors declared no other conflict of interests. 


\section{References}

1. Ghebreyesus TA WHO Director-General's Opening Remarks at the Media Briefing on COVID-19. Presented at the: 2020: World Health Organization; 2020.

2. Hsiang S, Allen D, Annan-Phan S, et al. The effect of large-scale anti-contagion policies on the COVID-19 pandemic. Nature. 2020;584(7820):262-267. doi:10.1038/s41586-020-2404-8

3. Chinazzi M, Davis JT, Ajelli M, et al. The effect of travel restrictions on the spread of the 2019 novel coronavirus (COVID-19) outbreak. Science. 2020;368(6489):395-400. doi:10.1126/science.aba9757

4. Bookwalter CM. Drug Shortages Amid the COVID-19 Pandemic. US Pharm. 2021;46(2):25-28.

5. Badreldin HA, Atallah B. Global drug shortages due to COVID-19: impact on patient care and mitigation strategies. Res Soc Adm Pharm. 2021;17(1):1946-1949. doi:10.1016/j.sapharm.2020.05.017

6. Saag MS. Misguided Use of Hydroxychloroquine for COVID-19. JAMA. 2020;324(21):2161. doi:10.1001/jama.2020.22389

7. $\mathrm{Hu} \mathrm{K}$, Guan W, Bi Y, et al. Efficacy and safety of Lianhuaqingwen capsules, a repurposed Chinese herb, in patients with coronavirus disease 2019: a multicenter, prospective, randomized controlled trial. Phytomedicine. 2021;85:153242. doi:10.1016/j.phymed.2020.153242

8. Zeng M, Li L, Wu Z. Traditional Chinese medicine Lianhua Qingwen treating Corona virus disease 2019(COVID-19): meta-analysis of randomized controlled trials. Serra Red. PLoS One. 2020;15(9):e0238828. doi:10.1371/journal.pone.0238828

9. Yang Y. Use of herbal drugs to treat COVID-19 should be with caution. Lancet. 2020;395(10238):1689-1690. doi:10.1016/ S0140-6736(20)31143-0

10. World Health Organization. WHO supports scientifically proven traditional medicine; 2020. Accessed April 23, 2021. https:// www.afro.who.int/news/who-supports-scientifically-proventraditional-medicine.

11. Ang L, Song E, Lee HW, Lee MS. Herbal medicine for the treatment of coronavirus disease 2019 (COVID-19): a systematic review and meta-analysis of randomized controlled trials. J Clin Med. 2020;9(5):1583. doi:10.3390/jcm9051583

12. Pu J, Mei H, Lei L, et al. Knowledge of medical professionals, their practices, and their attitudes toward traditional Chinese medicine for the prevention and treatment of coronavirus disease 2019: a survey in Sichuan, China. PLoS One. 2021;16(3): e0234855. doi:10.1371/journal.pone. 0234855

13. Xu S, Levine M. Medical residents' and students' attitudes towards herbal medicines: a pilot study. Can J Clin Pharmacol. 2008;15(1):e1-4.

14. Gyasi RM, Abass K, Adu-Gyamfi S, Accam BT. Nurses' knowledge, clinical practice and attitude towards unconventional medicine: implications for intercultural healthcare. Complement Ther Clin Pract. 2017;29:1-8. doi:10.1016/j.ctcp.2017.07.001

15. Hilal M, Hilal S. Knowledge, attitude, and utilization of herbal medicines by physicians in the Kingdom of Bahrain: a cross-sectional study. J Assoc Arab Univ Basic Appl Sci. 2017;24(1):325-333. doi:10.1016/j.jaubas.2016.11.001

16. Alzahrani SH, Bashawri J, Salawati EM, Bakarman MA. Knowledge and attitudes towards complementary and alternative medicine among senior medical students in King Abdulaziz University, Saudi Arabia. Evid Based Complement Altern Med. 2016;2016:9370721. doi:10.1155/2016/9370721

17. Shelley BM, Sussman AL, Williams RL, Segal AR, Crabtree BF. "They don't ask me so I don't tell them": patient-clinician communication about traditional, complementary, and alternative medicine. Ann Fam Med. 2009;7(2):139-147. doi:10.1370/ afm.947
18. Chaturvedi S, Kumar N, Tillu G, Deshpande S, Patwardhan B. AYUSH, modern medicine and the Covid-19 pandemic. Indian J Med Ethics. 2020;05(03):191-195. doi:10.20529/IJME.2020.058

19. Grimes DR. Medical disinformation and the unviable nature of COVID-19 conspiracy theories. Serra Red. PLoS One. 2021;16 (3):e0245900. doi:10.1371/journal.pone.0245900

20. Tillu G, Chaturvedi S, Chopra A, Patwardhan B. Public health approach of ayurveda and yoga for COVID-19 prophylaxis. J Altern Complement Med. 2020;26(5):360-364. doi:10.1089/ acm.2020.0129

21. Donma MM, Donma O. The effects of Allium sativum on immunity within the scope of COVID-19 infection. Med Hypotheses. 2020;144:109934. doi:10.1016/j.mehy.2020.109934

22. Batiha GE-S, Beshbishy AM, Wasef LG, et al. Chemical constituents and pharmacological activities of garlic (Allium sativum L.): a review. Nutrients. 2020;12(3):872. doi:10.3390/nu12030872

23. Keyaerts E, Vijgen L, Pannecouque C, et al. Plant lectins are potent inhibitors of coronaviruses by interfering with two targets in the viral replication cycle. Antiviral Res. 2007;75(3):179-187. doi:10.1016/j.antiviral.2007.03.003

24. Dandara C, Dzobo K, Chirikure S. COVID-19 pandemic and Africa: from the situation in Zimbabwe to a case for precision herbal medicine. Omi a J Integr Biol. 2021;25(4):209-212. doi:10.1089/omi.2020.0099

25. Mwai P. Coronavirus: what do we know about the Artemisia plant? BBC. Published 2020. Accessed June 22, 2021. https:// www.bbc.com/news/world-africa-53484298.

26. Cao R, Hu H, Li Y, et al. Anti-SARS-CoV-2 potential of artemisinins in vitro. ACS Infect Dis. 2020;6(9):2524-2531. doi:10.1021/acsinfecdis.0c00522

27. Gruessner BM, Cornet-Vernet L, Desrosiers MR, Lutgen P, Towler MJ, Weathers PJ. It is not just artemisinin: Artemisia sp. for treating diseases including malaria and schistosomiasis. Phytochem Rev. 2019;18(6):1509-1527. doi:10.1007/s11101019-09645-9

28. Rolta R, Salaria D, Kumar V, Sourirajan A, Dev K. Phytocompounds of Rheum emodi, Thymus serpyllum and Artemisia annua inhibit COVID-19 binding to ACE2 receptor: in silico approach. Res Sq Preprint. 2020. doi:10.21203/rs.3.rs30938/v1

29. Chikhale RV, Sinha SK, Patil RB, et al. In-silico investigation of phytochemicals from Asparagus racemosus as plausible antiviral agent in COVID-19. J Biomol Struct Dyn. 2021;39(14):5033-5047. doi:10.1080/07391102.2020.1784289

30. Bopana N, Saxena S. Asparagus racemosus - Ethnopharmacological evaluation and conservation needs. J Ethnopharmacol. 2007;110 (1):1-15. doi:10.1016/j.jep.2007.01.001

31. Alok S, Jain SK, Verma A, Kumar M, Mahor A, Sabharwal M. Plant profile, phytochemistry and pharmacology of Asparagus racemosus (Shatavari): a review. Asian Pacific J Trop Dis. 2013;3(3):242-251. doi:10.1016/S22221808(13)60049-3

32. Xu J, Zhang Y. Traditional Chinese Medicine treatment of COVID-19. Complement Ther Clin Pract. 2020;39:101165. doi:10.1016/j.ctcp.2020.101165

33. Li C, Wang L, Ren L. Antiviral mechanisms of candidate chemical medicines and traditional Chinese medicines for SARS-CoV-2 infection. Virus Res. 2020;286:198073. doi:10.1016/j. virusres.2020.198073

34. Fu L, Lin J, Yao M, Niu F, Ma F, Wang L. Clinical observation on treatment of cough during pregnancy with modified Baihe Gujin Decoction. Tradit Med Mod Med. 2020;03(02):117-122. doi:10.1142/S2575900020500081

35. Gupta H, Gupta M, Bhargava S. Potential use of turmeric in COVID-19. Clin Exp Dermatol. 2020;45(7):902-903. doi:10.1111/ced.14357 
36. Babaei F, Nassiri-Asl M, Hosseinzadeh H. Curcumin (a constituent of turmeric): new treatment option against COVID19. Food Sci Nutr. 2020;8(10):5215-5227. doi:10.1002/ fsn3. 1858

37. Emirik M. Potential therapeutic effect of turmeric contents against SARS-CoV-2 compared with experimental COVID-19 therapies: in silico study. J Biomol Struct Dyn. 2020;1-14. doi:10.1080/07391102.2020.1835719

38. Krup V. Pharmacological activities of turmeric (Curcuma longa Linn): a Review. J Homeopath Ayurvedic Med. 2013;2(4). doi:10.4172/2167-1206.1000133

39. Kumar SB, Krishna S, Pradeep S, et al. Screening of natural compounds from Cyperus rotundus Linn against SARS-CoV-2 main protease (Mpro): an integrated computational approach. Comput Biol Med. 2021;134:104524. doi:10.1016/j. compbiomed.2021.104524

40. Kamala A, Middha SK, Karigar CS. Plants in traditional medicine with special reference to Cyperus rotundus L.: a review. 3 Biotech. 2018;8(7):309. doi:10.1007/s13205-018-1328-6

41. Ren J, Zhang A-H, Wang X-J. Traditional Chinese medicine for COVID-19 treatment. Pharmacol Res. 2020;155:104743. doi:10.1016/j.phrs.2020.104743

42. Lee DYW, Li QY, Liu J, Efferth T. Traditional Chinese herbal medicine at the forefront battle against COVID-19: clinical experience and scientific basis. Phytomedicine. 2021;80:153337. doi:10.1016/j.phymed.2020.153337

43. Jiang M, Zhao S, Yang S, et al. An "essential herbal medicine"licorice: a review of phytochemicals and its effects in combination preparations. J Ethnopharmacol. 2020;249:112439. doi:10.1016/j.jep.2019.112439

44. Feng Yeh C, Chih Wang K, Chai Chiang L, Shieh DE, Hong Yen M, San Chang J. Water extract of licorice had anti-viral activity against human respiratory syncytial virus in human respiratory tract cell lines. J Ethnopharmacol. 2013;148 (2):466-473. doi:10.1016/j.jep.2013.04.040

45. Chrubasik S, Pittler MH, Roufogalis BD. Zingiberis rhizoma: a comprehensive review on the ginger effect and efficacy profiles. Phytomedicine. 2005;12(9):684-701. doi:10.1016/j. phymed.2004.07.009

46. Bailly C, Vergoten G. Glycyrrhizin: an alternative drug for the treatment of COVID-19 infection and the associated respiratory syndrome? Pharmacol Ther. 2020;214:107618. doi:10.1016/j. pharmthera.2020.107618

47. Keck T, Strobl A, Weinhaeusel A, Funk P, Michaelis M. Pelargonium extract EPs 7630 in the treatment of human corona virus-associated acute respiratory tract infections - a secondary subgroup-analysis of an open-label, uncontrolled clinical trial. Front Pharmacol. 2021;12. doi:10.3389/fphar.2021.666546

48. Michaelis M, Doerr HW, Cinatl J. Investigation of the influence of EPs $^{\circledR} 7630$, a herbal drug preparation from Pelargonium sidoides, on replication of a broad panel of respiratory viruses. Phytomedicine. 2011;18(5):384-386. doi:10.1016/j. phymed.2010.09.008

49. Conrad A, Kolodziej H, Schulz V. Pelargonium sidoides-Extrakt (EPs ${ }^{\circledR}$ 7630): zulassung bestätigt Wirksamkeit und Verträglichkeit. Wiener Medizinische Wochenschrift. 2007;157 (13-14):331-336. doi:10.1007/s10354-007-0434-6

50. Wu L, Chen Y, Ma Y, et al. Clinical practice guideline on treating influenza in adult patients with Chinese patent medicines. Pharmacol Res. 2020;160:105101. doi:10.1016/j.phrs.20 20.105101

51. Hu C, Liang M, Gong F, He B, Zhao D, Zhang G. Efficacy of Lianhua Qingwen compared with conventional drugs in the treatment of common pneumonia and COVID-19 pneumonia: a meta-analysis. Evid Based Complement Altern Med. 2020;2020:1-15. doi:10.1155/2020/5157089
52. Li L-C, Zhang Z-H, Zhou W-C, et al. Lianhua Qingwen prescription for coronavirus disease 2019 (COVID-19) treatment: advances and prospects. Biomed Pharmacother. 2020;130:110641. doi:10.1016/j.biopha.2020.110641

53. Wang C, Cao B, Liu -Q-Q, et al. Oseltamivir compared with the Chinese traditional therapy Maxingshigan-Yinqiaosan in the treatment of H1N1 influenza. Ann Intern Med. 2011;155(4):217. doi:10.7326/0003-4819-155-4-201108160-00005

54. Shao G, Huang S, Cui Y, Yang D. Maxingshigan decoction for treating COVID-19. Medicine. 2020;99(48):e23224. doi:10.1097/ MD.0000000000023224

55. Kageyama Y, Aida K, Kawauchi K, et al. Qingfei Paidu decoction, a Chinese herbal medicine against COVID-19, elevates the blood levels of pro-inflammatory cytokines: an open-label, single-arm pilot study. World Acad Sci J. 2021;3(3):25. doi:10.3892/ wasj.2021.96

56. Ren W, Ma Y, Wang R, et al. Research Advance on Qingfei Paidu Decoction in Prescription Principle, Mechanism Analysis and Clinical Application. Front Pharmacol. 2021;11. doi:10.3389/ fphar.2020.589714

57. Chen J, Wang Y, Gao Y, et al. Protection against COVID-19 injury by qingfei paidu decoction via anti-viral, anti-inflammatory activity and metabolic programming. Biomed Pharmacother. 2020;129:110281. doi:10.1016/j.biopha.20 20.110281

58. Poon PMK, Wong CK, Fung KP, et al. Immunomodulatory effects of a traditional Chinese medicine with potential antiviral activity: a self-control study. Am J Chin Med. 2006;34(01):13-21. doi:10.1142/S0192415X0600359X

59. Fang Z, Zhang M, Yi Z, Wen C, Qian M, Shi T. Replacements of rare herbs and simplifications of traditional Chinese medicine formulae based on attribute similarities and pathway enrichment analysis. Evid Based Complement Altern Med. 2013;2013:1-9. doi:10.1155/2013/136732

60. Yin L, Zeng Y, Huang X, Hou H. Effects of Forsythia suspensa extract on cell proliferation and activation of the mouse T lymphocytes in vitro. Chinese J Cell Mol Immunol. 2008;24(1):10-12.

61. Pi Q, Tan W, Tan Z. A narrative review of the scientific natures of the prevention and treatment of COVID-19 with traditional Chinese medicine. Longhua Chin Med. 2021;1:4.

62. Zhao Y, Pang X. Efficacy of Shegan Mahuang Decoction for asthma. Medicine. 2019;98(44):e17845. doi:10.1097/MD.000000 0000017845

63. Lin -C-C, Wang -Y-Y, Chen S-M, et al. Shegan-Mahuang Decoction ameliorates asthmatic airway hyperresponsiveness by downregulating Th2/Th17 cells but upregulating CD4+FoxP3+ Tregs. J Ethnopharmacol. 2020;253:112656. doi:10.1016/j. jep.2020.112656

64. Yang Y, Islam MS, Wang J, Li Y, Chen X. Traditional Chinese medicine in the treatment of patients infected with 2019-new coronavirus (SARS-CoV-2): a review and perspective. Int J Biol Sci. 2020;16(10):1708-1717. doi:10.7150/ijbs.45538

65. Zhang $\mathrm{H}$, Chen Q, Zhou W, et al. Chinese medicine injection shuanghuanglian for treatment of acute upper respiratory tract infection: a systematic review of randomized controlled trials. Evid Based Complement Altern Med. 2013;2013:1-7. doi: $10.1155 / 2013 / 987326$

66. Ni L, Wen Z, Hu X, et al. Effects of Shuanghuanglian oral liquids on patients with COVID-19: a randomized, open-label, parallel-controlled, multicenter clinical trial. Front Med. 2021 doi:10.1007/s11684-021-0853-6

67. Su H, Yao S, Zhao W, et al. Anti-SARS-CoV-2 activities in vitro of Shuanghuanglian preparations and bioactive ingredients. Acta Pharmacol Sin. 2020;41(9):1167-1177. doi:10.1038/s41401-0200483-6 
68. Ngbolua K-N, Mbadiko CM, Matondo A, et al. Review on ethno-botany, virucidal activity, phytochemistry and toxicology of Solanum genus: potential bio-resources for the therapeutic management of Covid-19. Eur J Nutr Food Saf. 2020:35-48. doi:10.9734/ejnfs/2020/v12i730246

69. Shree P, Mishra P, Selvaraj C, et al. Targeting COVID-19 (SARSCoV-2) main protease through active phytochemicals of ayurvedic medicinal plants - withania somnifera (Ashwagandha), Tinospora cordifolia (Giloy) and Ocimum sanctum (Tulsi) a molecular docking study. J Biomol Struct Dyn. 2020:1-14. doi:10.1080/07391102.2020.1810778

70. Ghosh S, Saha S. Tinospora cordifolia: one plant, many roles. Anc Sci Life. 2012;31(4):151. doi:10.4103/0257-7941.107344

71. Sabade M. Patho-physiology of COVID-19 and possible management principle from Ayurveda's perspective. Ann Ayurvedic Med. 2020;9(3):171-175. doi:10.5455/AAM.109096

72. Rathnayake H, De Zoysa MHN, Hewawasam RP, Weerasinghe MD. Comparison of In vitro antibacterial activity of Epaltes divaricata and Vetiveria zizanioides against methicillin-resistant Staphylococcus aureus. Scientifica. 2020;2020:1-8. doi:10.1155/2020/8239053

73. Kumar P, Chakraborthy GS, Mazumder A, Kumar K, Sodhi G, Rana SK. Ethnopharmacological and ethnomedicine properties of Vetiveria Zizanioides. Int J Allied Med Sci Clin Res. 2019;7:1.

74. Balkrishna A, Pokhrel S, Singh $\mathrm{H}$, et al. Withanone from Withania somnifera attenuates SARS-CoV-2 RBD and Host ACE2 interactions to rescue spike protein induced pathologies in humanized zebrafish model. Drug Des Devel Ther. 2021;15:1111-1133. doi:10.2147/DDDT.S292805

75. Gupta GL, Rana AC. Withania somnifera (Ashwagandha): a review. Pharmacogn Rev. 2007;1(1):129-136.

76. Davis L, Kuttan G. Immunomodulatory activity of Withania somnifera. J Ethnopharmacol. 2000;71(1-2):193-200. doi:10.1016/S0378-8741(99)00206-8

77. Guo H, Zheng J, Huang G, et al. Xuebijing injection in the treatment of COVID-19: a retrospective case-control study. Ann Palliat Care. 2020;9(5):5648.

78. Yin Q, Li C. Treatment effects of Xuebijing injection in severe septic patients with disseminated intravascular coagulation. Evid Based Complement Altern Med. 2014;2014:1-6. doi:10.1155/2014/949254

79. Li S, Wang H, Sun Q, Liu B, Chang X. Therapeutic effect of Xuebijing, a traditional Chinese medicine injection, on rheumatoid arthritis. Evid Based Complement Altern Med. 2020;2020:1-9. doi:10.1155/2020/2710782

80. Song Y, Yao C, Yao Y, et al. XueBiJing injection versus placebo for critically ill patients with severe community-acquired pneumonia. Crit Care Med. 2019;47(9):e735-e743. doi:10.1097/ CCM.0000000000003842

81. Yu J-S, Ho C-H, Hsu Y-C, Wang -J-J, Hsieh C-L. Traditional Chinese medicine treatments for upper respiratory tract infections/common colds in Taiwan. Eur J Integr Med. 2014;6 (5):538-544. doi:10.1016/j.eujim.2014.06.003

82. Liew WK, Loh W, Chiang WC, Goh A, Chay OM, Iancovici Kidon M. Pilot study of the use of Yin Qiao San in children with conventional antipyretic hypersensitivity. Asia Pac Allergy. 2015;5(4):222. doi:10.5415/apallergy.2015.5.4.222

83. Duan X-H, Liu L-S, Lei NL, Lin Q, Wang W-L, Yan H-W. The effects and mechanism of Yinqiao powder on upper respiratory tract infection. Int $J$ Biotechnol Wellness Ind. 2015;4(2):57-60. doi:10.6000/1927-3037.2015.04.02.2

84. Yang Z-S, Yan J-Y, Han N-P, et al. Anti-inflammatory effect of Yu-Ping-Feng-San via TGF- $\beta 1$ signaling suppression in rat model of COPD. Iran J Basic Med Sci. 2016;19(9):993-1002.

85. He T, Qu R, Qin C, et al. Potential mechanisms of Chinese Herbal Medicine that implicated in the treatment of COVID-19 related renal injury. Saudi Pharm J. 2020;28(9):1138-1148. doi:10.1016/ j.jsps.2020.08.002
86. Du CYQ, Zheng KYZ, Bi CW, Dong TTX, Lin H, Tsim KWK. Yu Ping Feng San, an ancient Chinese Herbal Decoction, induces gene expression of anti-viral proteins and inhibits neuraminidase activity. Phyther Res. 2015;29(5):656-661. doi:10.1002/ptr.5290

87. Cyranoski D. Why Chinese medicine is heading for clinics around the world. Nature. 2018;561(7724):448-450. doi:10.1038/d41586-018-06782-7

88. Mukherjee A, Banerjee M, Mandal V, Shukla AC, Mandal SC. Modernization of ayurveda: a brief overview of Indian initiatives. Nat Prod Commun. 2014;9(2):1934578X1400900. doi:10.1177/ 1934578X1400900239

89. Milden SP, Stokols D. Physicians' attitudes and practices regarding complementary and alternative medicine. Behav Med. 2004;30(2):73-84. doi:10.3200/BMED.30.2.73-84

90. Wahner-Roedler DL, Vincent A, Elkin PL, Loehrer LL, Cha SS, Bauer BA. Physicians' attitudes toward complementary and alternative medicine and their knowledge of specific therapies: a survey at an academic medical center. Evid Based Complement Altern Med. 2006;3(4):495-501. doi:10.1093/ecam/nel036

91. Wahner-Roedler DL, Lee MC, Chon TY, Cha SS, Loehrer LL, Bauer BA. Physicians' attitudes toward complementary and alternative medicine and their knowledge of specific therapies: 8-Year follow-up at an academic medical center. Complement Ther Clin Pract. 2014;20(1):54-60. doi:10.1016/j.ctcp.2013.09.003

92. Tengku Mohamad TAS, Islahudin F, Jasamai M, Jamal JA. Preference, perception and predictors of herbal medicine use among Malay women in Malaysia. Patient Prefer Adherence. 2019;13:1829-1837. doi:10.2147/PPA.S227780

93. Mothupi MC. Use of herbal medicine during pregnancy among women with access to public healthcare in Nairobi, Kenya: a cross-sectional survey. BMC Complement Altern Med. 2014;14 (1):432. doi:10.1186/1472-6882-14-432

94. Moreira D, Teixeira SS, Monteiro MHD, De-oliveira ACAX, Paumgartten FJR. Traditional use and safety of herbal medicines. Rev Bras Farmacogn. 2014;24(2):248-257. doi:10.1016/j.bjp.2014.03.006

95. World Health Organization. Traditional medicine; 2013. https:// apps.who.int/gb/ebwha/pdf_files/EB134/B134_24-en.pdf. Accessed 9 October, 2021.

96. Tabish SA. Complementary and alternative healthcare: is it evidence-based? Int J Heal Sci. 2008;2(1):5-9.

97. Du Toit A, van der Kooy F. Artemisia afra, a controversial herbal remedy or a treasure trove of new drugs? J Ethnopharmacol. 2019;244:112127. doi:10.1016/j.jep.2019.112127

98. Firenzuoli F, Gori L. Herbal medicine today: clinical and research issues. Evid Based Complement Altern Med. 2007;4(s1):37-40. doi:10.1093/ecam/nem096

99. Saghir SA, AlGabri NA, Alagawany MM, et al. Chloroquine and hydroxychloroquine for the prevention and treatment of COVID-19: a fiction, hope or hype? An updated review. Ther Clin Risk Manag. 2021;17:371-387. doi:10.2147/TCRM.S301817

100. Cavalcanti AB, Zampieri FG, Rosa RG, et al. Hydroxychloroquine with or without azithromycin in mild-tomoderate Covid-19. N Engl J Med. 2020;383(21):2041-2052. doi:10.1056/NEJMoa2019014

101. Skipper CP, Pastick KA, Engen NW, et al. Hydroxychloroquine in nonhospitalized adults with early COVID-19. Ann Intern Med. 2020;173(8):623-631. doi:10.7326/M20-4207

102. Hoffmann M, Mösbauer K, Hofmann-Winkler $H$, et al. Chloroquine does not inhibit infection of human lung cells with SARS-CoV-2. Nature. 2020;585(7826):588-590. doi:10.1038/ s41586-020-2575-3

103. Sriwijitalai W, Wiwanitkit V. Exaggerated information and COVID-19 outbreak. Eur J Clin Invest. 2020;50:5. doi:10.1111/ eci. 13226 
104. Niburski K, Niburski O. Impact of Trump's promotion of unproven COVID-19 treatments on social media and subsequent internet trends: observational study. J Med Internet Res. 2020;22(11): e20044. doi:10.2196/20044

105. Tollefson J. How Trump damaged science - and why it could take decades to recover. Nature. 2020;586(7828):190-194. doi:10.1038/d41586-020-02800-9

106. McLaughlin DM, Mewhirter J, Sanders R. The belief that politics drive scientific research \& its impact on COVID-19 risk assessment. PLoS One. 2021;16(4):e0249937. doi:10.1371/journal. pone.0249937

107. Agley J, Xiao Y. Misinformation about COVID-19: evidence for differential latent profiles and a strong association with trust in science. BMC Public Health. 2021;21(1):89. doi:10.1186/s12889020-10103-x

108. Caulfield T. Pseudoscience and COVID-19 - we've had enough already. Nature. 2020. doi:10.1038/d41586-020-01266-z

109. The House of Representatives of the Republic of Indonesia. House Proactively Joins the Fight against COVID-19. 2020. Accessed September 20, 2021. https://www.dpr.go.id/en/berita/ detail/id/28652/t/House+Proactively+Joins +the+Fight+against + COVID-19.

110. Enders AM, Uscinski JE, Klofstad C, Stoler J. The different forms of COVID-19 misinformation and their consequences. Harvard Kennedy Sch Misinformation Rev. 2020. doi:10.37016/ mr-2020-48

111. Demaio A. Local wisdom and health promotion: barrier or catalyst? Asia Pacific J Public Heal. 2011;23(2):127-132. doi:10.1177/1010539509339607

112. Ekor M. The growing use of herbal medicines: issues relating to adverse reactions and challenges in monitoring safety. Front Pharmacol. 2014;4. doi:10.3389/fphar.2013.00177
113. Nugraha RV, Ridwansyah H, Ghozali M, Khairani AF, Atik N. Traditional herbal medicine candidates as complementary treatments for COVID-19: a review of their mechanisms, pros and cons. Evid Based Complement Altern Med. 2020;2020:1-12. doi:10.1155/2020/2560645

114. Fan AY, Gu S, Alemi SF. Chinese herbal medicine for COVID-19: current evidence with systematic review and meta-analysis. J Integr Med. 2020;18(5):385-394. doi:10.1016/j. joim.2020.07.008

115. Thakkar S, Anklam E, Xu A, et al. Regulatory landscape of dietary supplements and herbal medicines from a global perspective. Regul Toxicol Pharmacol. 2020;114:104647. doi:10.1016/j.yrtph.2020.104647

116. Jones AW. Early drug discovery and the rise of pharmaceutical chemistry. Drug Test Anal. 2011;3(6):337-344. doi:10.1002/ dta.301

117. Fofana MO. Decolonising global health in the time of COVID-19. Glob Public Health. 2021;16(8-9):1155-1166. doi:10.1080/ 17441692.2020.1864754

118. Lau TF, Leung PC, Wong ELY, et al. Using herbal medicine as a means of prevention experience during the SARS crisis. Am $J$ Chin Med. 2005;33(03):345-356. doi:10.1142/S0192415X 05002965

119. Panyod S, Ho C-T, Sheen L-Y. Dietary therapy and herbal medicine for COVID-19 prevention: a review and perspective. $J$ Tradit Complement Med. 2020;10(4):420-427. doi:10.1016/j. jtcme.2020.05.004

120. Jonas WB. Building an evidence house: challenges and solutions to research in complementary and alternative medicine. Complement Med Res. 2005;12(3):159-167. doi:10.1159/ 000085412
Infection and Drug Resistance

\section{Publish your work in this journal}

Infection and Drug Resistance is an international, peer-reviewed openaccess journal that focuses on the optimal treatment of infection (bacterial, fungal and viral) and the development and institution of preventive strategies to minimize the development and spread of resistance. The journal is specifically concerned with the epidemiology of

\section{Dovepress}

antibiotic resistance and the mechanisms of resistance development and diffusion in both hospitals and the community. The manuscript management system is completely online and includes a very quick and fair peerreview system, which is all easy to use. Visit http://www.dovepress.com/ testimonials.php to read real quotes from published authors. 